\title{
Selection of common bean lines for calcium use efficiency ${ }^{1}$
}

\author{
Seleção de linhagens de feijão para eficiência no uso de cálcio
}

\author{
Lucas da Silva Domingues², Nerinéia Dalfollo Ribeiro*, Jerônimo Luiz Andriolo ${ }^{3}$, Micheli Thaise Della Flora \\ Possobom² e Allan Emanoel Mezzomo Zemolin²
}

\begin{abstract}
The study of the calcium use efficiency in common bean is unprecedented. Therefore, the objectives of this work were to evaluate the genetic variability of common bean lines for plant growth and grain yield characters, the calcium accumulation in different plant tissues at low and high calcium availabilities, and to select common bean lines with high calcium use efficiency and responsive to the calcium application by different indices. Twelve common bean lines were supplied with a nutrient solution at low $\left(1.10 \mathrm{mmol} \mathrm{L}^{-1}\right)$ and high $\left(3.85 \mathrm{mmol} \mathrm{L}^{-1}\right)$ calcium concentration and were evaluated. The L 15 line reached the higher values of dry mass of shoot, number of pods and grains per plant, number of grains per pod and grain yield at the low calcium concentration. Calcium accumulation in tissues was, on average, higher in leaves, followed by stems, pods and grains. The L 175 and L 159 lines have higher calcium concentration in grains (> $1.1 \mathrm{~g} \mathrm{~kg}^{-1} \mathrm{MS}$ ), regardless of the calcium concentration supplied to plants. The L15 line is efficient in calcium use. The L 221 and L 159 lines are responsive to the calcium application in the rooting medium.
\end{abstract}

Key words: Common bean. Plants-calcium effect. Grains-production.

RESUMO - O estudo da eficiência no uso de cálcio é inédita em feijão. Portanto, foram objetivos deste trabalho avaliar a variabilidade genética de linhagens de feijão para os caracteres do crescimento da planta e da produtividade de grãos e a acumulação de cálcio nos tecidos da planta em baixa e alta disponibilidade de cálcio e selecionar linhagens de feijão eficientes no uso de cálcio e responsivas a aplicação deste mineral por diferentes índices. Para tanto, 12 linhagens de feijão foram avaliadas em baixa $\left(1,10 \mathrm{mmol} \mathrm{L}^{-1}\right)$ e em alta $\left(3,85 \mathrm{mmol} \mathrm{L}^{-1}\right)$ concentração de cálcio na solução nutritiva. A linhagem L 15 produziu os maiores valores de massa seca de parte aérea, número de vagens e de grãos por planta, número de grãos por vagem e produtividade de grãos em baixa concentração de cálcio. A acumulação de cálcio nos tecidos foi, em média, maior nas folhas, seguidos pelos caules, vagens e grãos. As linhagens L 175 e L 159 possuem alta concentração de cálcio nos grãos (> $1,1 \mathrm{~g} \mathrm{~kg}^{-1}$ de MS), independente da concentração de cálcio fornecida às plantas. A linhagem L15 é eficiente no uso de cálcio. As linhagens L 221 e L 159 são responsivas à aplicação de cálcio no ambiente radicular.

Palavras-chave: Feijão. Plantas-efeito do cálcio. Grãos-produção.

\footnotetext{
*Autor para correspondência

${ }^{1}$ Recebido para publicação em 31/10/2013; aprovado em 09/06/2014

Parte da Tese de Doutorado do primeiro autor apresentada à Universidade Federal de Santa Maria/UFSM

${ }^{2}$ Programa de Pós-Graduação em Agronomia da UFSM, Santa Maria-RS, Brasil, lucassdomingues@hotmail.com, michepossobom@yahoo. com.br, allan_zemolin@hotmail.com

${ }^{3}$ Departamento de Fitotecnia, Centro de Ciências Rurais/UFSM, Cidade Universitária, Santa Maria-RS, Brasil, nerineia@hotmail.com, jeronimoandriolo@gmail.com
} 


\section{INTRODUCTION}

The common bean (Phaseolus vulgaris L.) in Brazil is cropped predominantly in marginal fields and for subsistence agriculture. Under these conditions, the correction of the soil fertility is not a currently practice and availability of calcium and other minerals for plant growth have been low. In this scenario, genetic breeding for the development of a more environmentally sustainable agriculture is presented as an alternative. This involves the selection and development of cultivars with higher nutrient use efficiency. The nutrient use efficiency can be defined as the relation between the amount of dry mass produced by unit of a nutrient absorbed by the plant (GOOD; SHRAWAT; MUENCH, 2004). The cultivars with higher nutrient use efficiency can reach higher growth and grain yield upon restricted environmental conditions.

The nutrient use efficiency is determined by the ratio between the biomass or the final product produced by plant and the amount of a nutrient supplied (FAGERIA, 1998), or relates to the nutrient use efficiency to physiological processes of absorption and of nutrient use (BAILIAN; MCKEAND; ALLEN, 1991). Comprehensive descriptions of indices that have been used to estimate the nutrient use efficiency of crops have been reported by Rose and Wissuwa (2012).

The index proposed by Siddiqi and Glass (1981) relates the nutrient use efficiency by plant growth. This index is one of the most widely used to determine nutrient use efficiency of crops and can be a tool to select efficient lines in breeding programs. It has been used for screening efficient and inefficient lines in rice (MENDONÇA et al., 2003), soybean (FURLANI et al., 2002) and corn (GONDIN et al., 2010) crops. In these experiments plant were grown in controlled conditions and fed by nutrient solutions during short periods varying from 30 to 50 days.

The response to nutrient application, in turn, is estimated by the ratio between the differences in biomass production or grain yield and nutrient availability (FURTINI, 2008). The response to nutrient application aims to observe the performance of genotypes in different nutrient concentrations supplied to plant.

For the common bean crop, selection of lines for nutrient use efficiency in breeding programs has been focused mainly in nitrogen (SANTOS; FAGERIA, 2007; SOUZA et al., 2012), phosphorus (FAGERIA et al., 2010; HENRY et al., 2010) and potassium (FAGERIA; BARBOSA FILHO; COSTA, 2001). Results for calcium use efficiency were not found in the literature for this crop. Nevertheless, there are important agricultural and nutritional reasons to select for this character. Plant growth and grain yield is a consequence of complex physiological processes such as organization of cell walls, stabilization of membranes, cell signaling, hormonal induction, pollen germination and pollen tube growth, and root elongation (GE; TIAN; RUSSEL, 2007; GILLIHAM et al., 2011). All of these processes are influenced or calcium-dependent. In turn, calcium accumulation in grains is an important nutritional character, considering that the common bean is the main dietary ingredient of Brazilian people.

The objectives of this research were to evaluate the genetic variability of common bean lines for plant growth and grain yield characters, the calcium accumulation in different plant tissues at low and high calcium availabilities, and to select common bean lines with high calcium use efficiency and responsive to the calcium application by different indices.

\section{MATERIALS AND METHODS}

The experiment was performed in closed soilless system inside a greenhouse at the Plant Science Department of the Federal University of Santa Maria, Santa Maria, Rio Grande do Sul, Brazil (lat 2942' S, long 5349' W and 95 $\mathrm{m}$ altitude), from March to June 2012. The growing device consisted of six $0.85 \mathrm{~m}$ height concrete benches bearing an ondulated fiber cement tile, $3.60 \mathrm{~m}$ long and $1.10 \mathrm{~m}$ wide, at $1 \%$ slope. Plants were grown in $4 \mathrm{dm}^{3}$ black polypropylene pots filled with sand (1.2 to $2.4 \mathrm{~mm}$ gauge), previously washed with a $1 \%$ sodium hypochlorite solution. There were 48 pots per bench in four lines, $5 \mathrm{~cm}$ apart between lines and $30 \mathrm{~cm}$ between pots, with one plant per pot.

The experiment was conducted in a completely randomized design with split plots and six repetitions. The main plots consisted of two calcium concentrations in the nutrient solution: low $\left(1.10 \mathrm{mmol} \mathrm{L}^{-1}\right)$ and high (3.85 mmol L-1). Twelve common bean lines were grow in sub-plots, whereas 10 inbred lines in $\mathrm{F}_{8}$ generation of the Bean Breeding Program at Federal University of Santa Maria and two control lines (commercial cultivars): BRS Expedito and Carioca. All lines evaluated are from the Middle American gene pool, having black or carioca (beige with brown streaks) tegument, with mass of 100 grains lower than $25 \mathrm{~g}$ and differing in calcium concentration in the grains.

The nutrient solutions were prepared in six 310 L fiberglass tanks and supplied to plants by means of a submersible pump connected to drip tubing. In nutrient solution with low calcium concentration $\left(1.10 \mathrm{mmol} \mathrm{L}^{-1}\right)$ were used the following fertilizer salt concentrations (in $\mathrm{mg} \mathrm{L}^{-1}$ ): $227.60 \mathrm{Ca}\left(\mathrm{NO}_{3}\right)_{2}, 246.50 \mathrm{MgSO}_{4}, 40.00$ $\mathrm{NH}_{4} \mathrm{NO}_{3}, 204.15 \mathrm{KH}_{2} \mathrm{PO}_{4}$ and $303.30 \mathrm{KNO}_{3}$ In nutrient solution with high calcium concentration $\left(3.85 \mathrm{mmol} \mathrm{L}^{-1}\right)$ were used the following fertilizer salt concentrations (in $\mathrm{mg} \mathrm{L}^{-1}$ ): $796.60 \mathrm{Ca}\left(\mathrm{NO}_{3}\right)_{2}, 369.75 \mathrm{MgSO}_{4}, 87.15$ 
$\mathrm{K}_{2} \mathrm{SO}_{4}$ and 136.10 of $\mathrm{KH}_{2} \mathrm{PO}_{4}$. Concentrations of other nutrients in the nutrient solution were adjusted to maintain the ionic equilibrium. Following, were added $0.1 \mathrm{ml} \mathrm{L}^{-1}$ solution containing micronutrients, except iron which was provided as a chelate at a concentration of $20 \mathrm{mg} \mathrm{L}^{-1}$, for the two solutions formulated.

The volume of nutrient solution exceeding the sand water retention capacity drained back to each reservoir and was recirculated. Four daily $15 \mathrm{~min}$ fertigations were done, controlled by a timer. The electrical conductivity (EC) was measured every 48 hours, and whenever a deviation of more than $10 \%$ from the initial value was recorded, water or aliquots of new nutrient solution were added as required. The $\mathrm{pH}$ was maintained between 5.5 and 6.5 with the addition of $\mathrm{KOH}$ or $\mathrm{H}_{2} \mathrm{SO}_{4}$ solutions at $1 \mathrm{~N}$ (Eq. L-1) concentration whenever necessary. The nutrient solution was completely renewed whenever the volume inside the reservoir reached $103 \mathrm{~L}$.

At pod filling (R8) stage, six plants were collected from each treatment for determination of the dry mass of plant. Dry mass of shoot (leaves and stems), pods and roots were determined after drying in an oven with forced air circulation $\left(65-70{ }^{\circ} \mathrm{C}\right)$ until constant mass was reached. The shoot/root ratio was obtained by the ratio between dry mass of shoot and dry mass of roots of the plant. At maturation (R9) stage another six plants of each treatment were collected and number of pods and grains per plant, number of grains per pod and grain yield ( $\mathrm{g}$ plant ${ }^{-1}$, at $13 \%$ average moisture) were determined.

A sample of $5 \mathrm{~g}$ of dry mass of leaves, stems and pods at R8 stage and grains at R9 stage was finely grounded in an analytical knife mill to obtain particles smaller than $1 \mathrm{~mm}$. Next, a $0.5 \mathrm{~g}$ sample of the flour obtained was taken randomly and digested in $5 \mathrm{ml}$ of an acid solution composed of nitric acid $\left(\mathrm{HNO}_{3}\right)$ and perchloric acid $\left(\mathrm{HClO}_{4}\right)$ in the volumetric ratio of $3: 1$, using the methodology described by Miyazawa, Pavan and Bloch (1999). The determination of the calcium concentration in different tissues was performed in an atomic absorption spectrophotometer using a wavelength of $422.70 \mathrm{~nm}$.

The calcium use efficiency was determined with the use of different indices adapted from Siddiqi and Glass (1981): (1) calcium use efficiency in grains (UEG) $=(\mathrm{g} \text { grain yield })^{2} .(\mathrm{mg} \text { of Ca accumulated in the grains })^{-1}$; (2) calcium use efficiency in shoot $(\mathrm{UES})=(\mathrm{g}$ dry mass of shoot $)^{2}$. (mg of $\mathrm{Ca}$ accumulated in the shoot $)^{-1}$; (3) calcium use efficiency in plant $(\mathrm{UEP})=(\mathrm{g}$ dry mass of shoot and grains $)^{2}$. (mg of $\mathrm{Ca}$ accumulated in the shoot and grains $)^{-1}$; (4) calcium acquisition efficiency $(\mathrm{CAE})=$ (mg of $\mathrm{Ca}$ accumulated in shoot and grains) ${ }^{2}$. (mg of $\mathrm{Ca}$ supplied in the nutrient solution $)^{-1}$; (5) calcium use efficiency in grain production $(\mathrm{UEGP})=(\mathrm{g} \text { grain yield })^{2}$. ( $\mathrm{mg}$ of $\mathrm{Ca}$ accumulated in shoot and grains) ${ }^{-1}$.
The response of common bean lines to the calcium application in the nutrient solution was evaluated using a methodology adapted from Furtini (2008), from the following response indices: (1) calcium response index to grain production (RIGP) $=\left[\left(\mathrm{GY}_{\mathrm{A}}-\mathrm{GY}_{\mathrm{B}}\right)(\mathrm{A}-\mathrm{B})^{-1}\right]$, whereas: $\mathrm{GY}_{\mathrm{A}}$ and $\mathrm{GY}_{\mathrm{B}}$ correspond to grain yield $\left(g\right.$ planta $\left.^{-1}\right)$ at high and low calcium concentrations; $A-B$ is the difference between the different calcium concentrations in the nutrient solution $\left(\mathrm{mg} \mathrm{L}^{-1}\right)$; (2) calcium response index to shoot dry mass production (RISDM) = $\left[\left(\mathrm{DMS}_{\mathrm{A}}-\mathrm{DMS}_{\mathrm{B}}\right)(\mathrm{A}-\mathrm{B})^{-1}\right]$, whereas: $\mathrm{DMS}_{\mathrm{A}}$ and $\mathrm{DMS}_{\mathrm{B}}$ correspond to dry mass of shoot $(\mathrm{g})$ at high and low calcium concentrations; A-B is the difference between the different calcium concentrations in the nutrient solution $\left(\mathrm{mg} \mathrm{L}^{-1}\right)$; (3) calcium response index to plant dry mass production $($ RIPDM $)=\left[\left(\mathrm{DMSG}_{\mathrm{A}}-\mathrm{DMSG}_{\mathrm{B}}\right)\right.$ $(\mathrm{A}-\mathrm{B})^{-1}$ ], whereas: $\mathrm{DMSG}_{\mathrm{A}}$ and $\mathrm{DMSG}_{\mathrm{B}}$ correspond to dry mass of shoot and grain yield $(\mathrm{g})$ at high and low calcium concentrations; A-B is the difference between the different calcium concentrations in the nutrient solution $\left(\mathrm{mg} \mathrm{L}^{-1}\right)$.

Based in the calcium use efficiency and calcium response indices were made graphs relating the two parameters. For that, it was plotted at $x$-axis the efficiency index in low calcium concentration, and at $y$-axis was plotted the calcium response index. The $x$ and $y$ axes have had their origin transposed in the mean values of the calcium use efficiency and calcium response indices. Four graphs were made relating the efficiency and response to shoot dry mass production, the efficiency and the response to plant dry mass production (shoot and grains), acquisition efficiency and response to grain production and efficiency and response to grain production. Thus, the common bean lines were classified according by Batten, Khan and Cullis (1984) into four categories: efficient and responsive (ER), inefficient and responsive (INR), inefficient and unresponsive (INUR) and efficient and unresponsive (EUR).

The data obtained were submitted to variance analysis considering the completely randomized design with split plots and six repetitions, except for determination of the calcium concentration in tissues and for estimates of calcium use efficiency and calcium response indices, for which three repetitions were used. The F test ( $p$ value $<0.05$ ) was used for testing the hypotheses of main effects and of the calcium concentration $x$ line interaction, considering all effects as fixed. The comparison of means between the two calcium concentrations was carried by Student's $t$ test ( $\mathrm{p}$ value $=0.05)$, whereas means obtained by different lines were compared by Scott-Knott's test ( $\mathrm{p}$ value $=0.05$ ). Analyses were performed with the aid of Microsoft Excel and Genes softwares (CRUZ, 2013). 


\section{RESULTS AND DISCUSSION}

In the variance analysis, significant effects were observed for calcium concentration, line and calcium concentration $\mathrm{x}$ line interaction for plant growth characters (dry mass of shoot, pods and roots and shoot/root ratio), grain yield characters (number of pods and grains per plant, number of grains per pod and grain yield), calcium concentration (in leaves, stems, pods and grains) and for the calcium use efficiency (in grains, in shoot, in plant, in acquisition and in grain production) indices.

Common bean lines with dry mass of shoot higher than the BRS Expedito and Carioca cultivars were identified in grown at low (L 15, L 74, L 234, L 246 and L 77) and high calcium concentration (L 15 and L 221) (Table 1). Moreover, the response of the common bean lines to the increasing calcium availability in the rooting medium was not constant for dry mass of shoot. The Carioca, L 236, L 175, L 15, L 200, L 221, L 159 and L 77 lines showed higher dry mass of shoot at high calcium concentration in the rooting medium. Similar results were reported by Silva; Moraes and Souza (2011) in common bean plants of the Talismã cultivar. However, in the present experiment, at high calcium concentration was recorded a reduction in dry mass of shoot on L 74 and L 246 lines and no effect on BRS Expedito cultivar and L 234 line. Therefore, presented data suggest a genetic effect contributing to the common bean response to calcium availability in the rooting medium.

Dry mass of pods was highest on L 77 line plants at low and high calcium availability (Table 1). An increase in dry mass of pods by effect of the high calcium concentration in the nutrient solution was recorded only for L 236 and L 159 lines. However, it is noteworthy the low values of dry mass of pods of both lines, when compared with that of L 77 line. For the other lines, the increase in calcium concentration in the nutrient solution did not increase the dry mass of pods. Similar results were obtained by Favaro et al. (2007) in snap beans.

The lines that showed higher dry mass of roots at low calcium concentration were L 74, L 221, L 246 and L77 and at high calcium concentration, L 221 and L 159 (Table 1). In soybean cultivars supplied with nutrient solutions at different calcium concentrations, Spehar and Galwey (1997) reported significant calcium concentration $\mathrm{x}$ cultivar interactions in root elongation and growth of secondary roots and concluded that soybean cultivars presented different calcium requirements for root growth. In the present work, we observe that the L 74, L 221, L 246 and L77 lines showed high root growth at low calcium availability and the selection of these lines is promising for the breeding program. Plants being able to growth roots in low fertility soils can explore it in a deeper and more extensive way as a compensatory mechanism to sustain plant growth and grain yield.
The shoot/root ratio was increased at the higher calcium concentration in the nutrient solution for all lines, except for L 175 (Table 1). This is worthy, because a vigorous shoot growth can enhance leaf surface growth, photosynthetic rate and grain yield.

The high calcium concentration in the nutrient solution increased the mean value for number of pods and of grains per plant, number grains per pod and grain yield (Table 1). Similar effects were recorded by Favaro et al. (2007) in number of green pods on snap bean plants grown in the high calcium concentration in the nutrient solution at 10 to 12 days after anthesis of flowers. Such effect has been attributed to low abortion of flowers and pods, because pollen germination and pollen tube growth is enhanced by calcium (GE; TIAN; RUSSEL, 2007).

Nevertheless, the higher values of number of pods and of grains per plant, number of grains per pod and grain yield were recorded on $\mathrm{L} 15$ line plants grown at low calcium concentration in the nutrient solution (Table 1). Although it can seem contradictory, it can be explained by the vigorous shoot growth of this line under low calcium availability. The L 15 line showed a low calcium requirement for the dry mass of shoot and grain yield characters and must be selected by the breeding program. Nevertheless, the fact that shoot growth of this line was also increased at high calcium availability while grain yield characters decreased is a matter for further research.

The L 15, L 234, L 246 and L77 lines grown at low calcium concentration showed higher grain yield than BRS Expedito and Carioca cultivars (Table 1). At high calcium concentration, the higher grain yield was obtained by L 77 line. In the present work, it was possible to identify responsive common bean lines to an increase in the calcium availability to plants: BRS Expedito, Carioca, L 236, L 175, L 200, L 74, L 221, L 159, L 234 and L 77. Therefore, the common bean lines developed by the Bean Breeding Program at Federal University of Santa Maria showed genetic variability for plant growth and grain yield characters upon contrasting calcium availabilities, enabling further selection for grown in environments with and without calcium restriction.

Calcium accumulation in plant organs of the common bean lines was higher in leaves, followed by stems, pods and grains (Table 2). In snap bean grown in nutrient solution, Pomper and Grusak (2004) also observed that leaves were the highest calcium accumulator, followed by stems. In the present work, it was also found an increasing in calcium concentration of plant organs at high calcium availability in the nutrient solution. Therefore, calcium fertilization may be effective to increase the average calcium accumulation in the edible portions of the common bean plant, thus improving the nutritional value of this legume. 
The mean calcium concentration in leaves increased $63.39 \%$ at the high concentration in the nutrient solution, from $16.39 \mathrm{~g} \mathrm{~kg}^{-1}$ of dry matter (DM) at the low concentration to $26.78 \mathrm{~g} \mathrm{~kg}^{-1} \mathrm{DM}$ at the high concentration (Table 2). In grains, the mean was $0.98 \mathrm{~g} \mathrm{~kg}^{-1} \mathrm{DM}$ at the high calcium concentration, reaching on average 27 times more calcium than in leaves of plants grown under the same condition. Calcium is transported mainly by the water flux through the xylem and its mobility is low in the phloem (FROSSARD et al., 2000). Thus, its lower accumulation in grains than in leaves can be attributed to the low water demand of grains during its growth.

Table 1 - Mean values* for dry mass of shoot (DMS, g), dry mass of pods (DMP, g), dry mass of roots (DMR, g), shoot/roots ratio (S/R), number of pods (NP), number of grains (NG), number of grains per pod (NGP) and grain yield (yield, $\mathrm{g}^{\text {planta }}{ }^{-1}$ ) obtained for 12 common bean lines grown under two calcium concentrations in the nutrient solution

\begin{tabular}{|c|c|c|c|c|c|c|c|c|}
\hline \multirow{2}{*}{ Line } & \multicolumn{2}{|c|}{ DMS } & \multicolumn{2}{|c|}{ DMP } & \multicolumn{2}{|c|}{ DMR } & \multicolumn{2}{|c|}{$\mathrm{S} / \mathrm{R}$} \\
\hline & Low $\mathrm{Ca}$ & High $\mathrm{Ca}$ & Low $\mathrm{Ca}$ & High $\mathrm{Ca}$ & Low $\mathrm{Ca}$ & High $\mathrm{Ca}$ & Low $\mathrm{Ca}$ & High $\mathrm{Ca}$ \\
\hline BRS Expedito & $10.4 \mathrm{dA}$ & $9.4 \mathrm{fA}$ & $4.6 \mathrm{fA}$ & $2.0 \mathrm{eB}$ & $1.5 \mathrm{bA}$ & $0.8 \mathrm{bB}$ & $10.4 \mathrm{~dB}$ & $15.1 \mathrm{bA}$ \\
\hline Carioca & $10.2 \mathrm{~dB}$ & $19.5 \mathrm{cA}$ & $5.8 \mathrm{eA}$ & $6.2 \mathrm{cA}$ & $1.4 \mathrm{bA}$ & $1.4 \mathrm{bA}$ & $11.4 \mathrm{~dB}$ & $18.2 \mathrm{aA}$ \\
\hline L 236 & $9.8 \mathrm{~dB}$ & $17.3 \mathrm{dA}$ & $4.7 \mathrm{fB}$ & $5.8 \mathrm{cA}$ & $1.6 \mathrm{bA}$ & $1.2 \mathrm{bA}$ & $9.5 \mathrm{~dB}$ & $20.5 \mathrm{aA}$ \\
\hline L 175 & $8.5 \mathrm{eB}$ & $11.3 \mathrm{eA}$ & $5.4 \mathrm{eA}$ & $3.6 \mathrm{~dB}$ & $0.8 \mathrm{bA}$ & $1.1 \mathrm{bA}$ & $17.9 \mathrm{cA}$ & $13.8 \mathrm{cB}$ \\
\hline L 15 & $19.8 \mathrm{aB}$ & $22.5 \mathrm{bA}$ & $13.4 \mathrm{bA}$ & $9.7 \mathrm{bB}$ & $1.5 \mathrm{bA}$ & $1.6 \mathrm{bA}$ & $23.6 \mathrm{aA}$ & $20.7 \mathrm{aA}$ \\
\hline L 200 & $8.3 \mathrm{eB}$ & $17.6 \mathrm{dA}$ & $11.7 \mathrm{cA}$ & $6.6 \mathrm{cB}$ & $1.0 \mathrm{bA}$ & $1.2 \mathrm{bA}$ & $20.3 \mathrm{bA}$ & $21.2 \mathrm{aA}$ \\
\hline L 74 & $12.4 \mathrm{cA}$ & $7.7 \mathrm{gB}$ & $13.8 \mathrm{bA}$ & $2.6 \mathrm{eB}$ & $1.7 \mathrm{aA}$ & $0.9 \mathrm{bB}$ & $15.2 \mathrm{cA}$ & $12.4 \mathrm{cA}$ \\
\hline L 221 & $10.1 \mathrm{~dB}$ & $26.3 \mathrm{aA}$ & $2.9 \mathrm{gA}$ & $3.4 \mathrm{dA}$ & $2.1 \mathrm{aA}$ & $2.1 \mathrm{aA}$ & $6.3 \mathrm{eB}$ & $14.1 \mathrm{cA}$ \\
\hline L 159 & $7.6 \mathrm{eB}$ & $17.2 \mathrm{dA}$ & $5.3 \mathrm{eB}$ & $9.0 \mathrm{bA}$ & $1.1 \mathrm{bB}$ & $2.3 \mathrm{aA}$ & $11.9 \mathrm{dA}$ & $11.6 \mathrm{cA}$ \\
\hline L 234 & $16.7 \mathrm{bA}$ & $17.1 \mathrm{dA}$ & $10.6 \mathrm{dA}$ & $6.7 \mathrm{cB}$ & $1.5 \mathrm{bA}$ & $1.4 \mathrm{bA}$ & $18.9 \mathrm{cA}$ & $17.2 \mathrm{bA}$ \\
\hline L 246 & $16.6 \mathrm{bA}$ & $12.4 \mathrm{eB}$ & $14.0 \mathrm{bA}$ & $6.2 \mathrm{cB}$ & $2.4 \mathrm{aA}$ & $1.1 \mathrm{bB}$ & $12.7 \mathrm{~dB}$ & $16.3 \mathrm{bA}$ \\
\hline L 77 & $16.7 \mathrm{bB}$ & $20.4 \mathrm{cA}$ & $16.2 \mathrm{aA}$ & $10.6 \mathrm{aB}$ & $2.0 \mathrm{aA}$ & $1.4 \mathrm{bA}$ & $17.8 \mathrm{cB}$ & $22.3 \mathrm{aA}$ \\
\hline Mean & 12.25 & 16.56 & 9.03 & 6.04 & 1.54 & 1.37 & 14.65 & 16.94 \\
\hline C.V.\% & & 8.30 & & 10.17 & & 13.28 & & 17.84 \\
\hline \multirow{2}{*}{ Line } & \multicolumn{2}{|c|}{$\mathrm{NP}$} & \multicolumn{2}{|c|}{$\mathrm{NG}$} & \multicolumn{2}{|c|}{ NGP } & \multicolumn{2}{|c|}{ Yield } \\
\hline & Low $\mathrm{Ca}$ & High $\mathrm{Ca}$ & Low $\mathrm{Ca}$ & High $\mathrm{Ca}$ & Low $\mathrm{Ca}$ & High Ca & Low $\mathrm{Ca}$ & High Ca \\
\hline BRS Expedito & $8.0 \mathrm{~dB}$ & $10.7 \mathrm{eA}$ & $30.7 \mathrm{~dB}$ & $46.7 \mathrm{cA}$ & $3.8 \mathrm{cB}$ & $4.4 \mathrm{bA}$ & $6.58 \mathrm{~dB}$ & $14.51 \mathrm{dA}$ \\
\hline Carioca & $15.5 \mathrm{aA}$ & $15.5 \mathrm{bA}$ & $44.5 \mathrm{cB}$ & $64.0 \mathrm{bA}$ & $2.9 \mathrm{~dB}$ & $4.1 \mathrm{cA}$ & $9.31 \mathrm{cB}$ & $16.56 \mathrm{bA}$ \\
\hline L 236 & $7.7 \mathrm{dA}$ & $9.2 \mathrm{fA}$ & $33.2 \mathrm{~dB}$ & $42.7 \mathrm{cA}$ & $4.3 \mathrm{bB}$ & $4.7 \mathrm{bA}$ & $5.87 \mathrm{eB}$ & $15.29 \mathrm{cA}$ \\
\hline L 175 & $6.5 \mathrm{~dB}$ & $7.5 \mathrm{gA}$ & $31.2 \mathrm{~dB}$ & $39.8 \mathrm{cA}$ & $4.8 \mathrm{bB}$ & $5.3 \mathrm{aA}$ & $5.09 \mathrm{eB}$ & $10.54 \mathrm{fA}$ \\
\hline L 15 & $15.7 \mathrm{aA}$ & $10.5 \mathrm{eB}$ & $80.8 \mathrm{aA}$ & $58.8 \mathrm{bB}$ & $5.2 \mathrm{aA}$ & $5.6 \mathrm{aA}$ & $19.06 \mathrm{Aa}$ & $12.79 \mathrm{eb}$ \\
\hline L 200 & $9.0 \mathrm{cB}$ & $21.7 \mathrm{aA}$ & $28.2 \mathrm{~dB}$ & $89.3 \mathrm{aA}$ & $3.1 \mathrm{~dB}$ & $4.1 \mathrm{cA}$ & $4.49 \mathrm{eB}$ & $12.61 \mathrm{eA}$ \\
\hline L 74 & $9.8 \mathrm{cB}$ & $13.7 \mathrm{cA}$ & $47.8 \mathrm{cB}$ & $61.3 \mathrm{bA}$ & $4.9 \mathrm{bA}$ & $4.5 \mathrm{bB}$ & $6.62 \mathrm{~dB}$ & $13.62 \mathrm{dA}$ \\
\hline L 221 & $7.8 \mathrm{~dB}$ & $12.0 \mathrm{dA}$ & $35.8 \mathrm{~dB}$ & $55.0 \mathrm{bA}$ & $4.6 \mathrm{bA}$ & $4.6 \mathrm{bA}$ & $7.16 \mathrm{~dB}$ & $14.12 \mathrm{dA}$ \\
\hline L 159 & $8.2 \mathrm{~dB}$ & $10.8 \mathrm{eA}$ & $38.5 \mathrm{cB}$ & $59.2 \mathrm{bA}$ & $4.7 \mathrm{bB}$ & $5.5 \mathrm{aA}$ & $7.06 \mathrm{~dB}$ & $14.98 \mathrm{cA}$ \\
\hline L 234 & $8.7 \mathrm{cB}$ & $13.8 \mathrm{cA}$ & $41.5 \mathrm{cB}$ & $55.7 \mathrm{bA}$ & $4.8 \mathrm{bA}$ & $4.0 \mathrm{cB}$ & $11.48 \mathrm{bB}$ & $16.11 \mathrm{bA}$ \\
\hline L 246 & $11.8 \mathrm{bB}$ & $16.2 \mathrm{bA}$ & $43.5 \mathrm{cB}$ & $62.7 \mathrm{bA}$ & $3.7 \mathrm{cA}$ & $3.9 \mathrm{cA}$ & $19.84 \mathrm{aA}$ & $17.17 \mathrm{bB}$ \\
\hline L 77 & $12.2 \mathrm{bA}$ & $12.2 \mathrm{dA}$ & $65.8 \mathrm{bA}$ & $62.8 \mathrm{bA}$ & $5.4 \mathrm{aA}$ & $5.1 \mathrm{aA}$ & $11.76 \mathrm{bB}$ & $19.28 \mathrm{aA}$ \\
\hline Mean & 10.07 & 12.81 & 43.46 & 58.17 & 4.35 & 4.65 & 9.53 & 14.80 \\
\hline C.V.\% & & 10.49 & & 13.05 & & 8.35 & & 9.43 \\
\hline
\end{tabular}

*Means not followed by the same lowercase letter on the column differ by Scott-Knott's test (p-value=0.05) and uppercase letter on the line differ by Student's $t$-test $(\mathrm{p}$-value $=0.05)$ 
Table 2 - Mean values* for calcium concentration in leaves (Ca leaves, $\mathrm{g} \mathrm{kg}^{-1}$ of dry mass - DM), calcium concentration in stems (Ca stems, $\mathrm{g} \mathrm{kg}^{-1}$ of DM), calcium concentration in the pods (Ca pods, $\mathrm{g} \mathrm{kg}^{-1}$ of DM) and calcium concentration in the grains (grains $\mathrm{Ca}, \mathrm{g} \mathrm{kg}^{-1}$ of DM) obtained for 12 common bean lines grown under two calcium concentrations in the nutrient solution

\begin{tabular}{lccrrrrrr}
\hline \multirow{2}{*}{ Line } & \multicolumn{2}{c}{ Ca leaves } & \multicolumn{2}{c}{ Ca stems } & \multicolumn{2}{c}{ Ca pods } & \multicolumn{2}{c}{ Ca grains } \\
\cline { 2 - 9 } & Low Ca & High Ca & Low Ca & High Ca & Low Ca & High Ca & Low Ca & High Ca \\
\hline BRS Expedito & $14.0 \mathrm{bB}$ & $27.0 \mathrm{bA}$ & $3.4 \mathrm{~dB}$ & $8.5 \mathrm{dA}$ & $2.3 \mathrm{aB}$ & $3.0 \mathrm{bA}$ & $1.4 \mathrm{aA}$ & $1.3 \mathrm{aA}$ \\
Carioca & $16.9 \mathrm{aB}$ & $26.9 \mathrm{bA}$ & $3.2 \mathrm{~dB}$ & $9.2 \mathrm{cA}$ & $2.5 \mathrm{aA}$ & $3.0 \mathrm{bA}$ & $1.0 \mathrm{aA}$ & $1.0 \mathrm{bA}$ \\
L 236 & $12.5 \mathrm{bB}$ & $23.3 \mathrm{cA}$ & $3.8 \mathrm{cB}$ & $6.7 \mathrm{eA}$ & $2.2 \mathrm{aB}$ & $3.3 \mathrm{bA}$ & $1.1 \mathrm{aA}$ & $0.9 \mathrm{bA}$ \\
L 175 & $14.4 \mathrm{bB}$ & $27.4 \mathrm{bA}$ & $4.1 \mathrm{cB}$ & $10.0 \mathrm{bA}$ & $1.4 \mathrm{aB}$ & $2.8 \mathrm{bA}$ & $1.1 \mathrm{aA}$ & $1.4 \mathrm{aA}$ \\
L 15 & $17.6 \mathrm{aB}$ & $23.8 \mathrm{cA}$ & $5.5 \mathrm{bB}$ & $8.3 \mathrm{dA}$ & $1.9 \mathrm{aB}$ & $2.6 \mathrm{bA}$ & $0.6 \mathrm{bB}$ & $1.0 \mathrm{bA}$ \\
L 200 & $17.2 \mathrm{aB}$ & $26.6 \mathrm{bA}$ & $3.3 \mathrm{~dB}$ & $8.2 \mathrm{dA}$ & $2.0 \mathrm{aB}$ & $4.1 \mathrm{aA}$ & $1.1 \mathrm{aA}$ & $0.9 \mathrm{bA}$ \\
L 74 & $17.3 \mathrm{aB}$ & $26.7 \mathrm{bA}$ & $4.0 \mathrm{cB}$ & $11.9 \mathrm{aA}$ & $1.6 \mathrm{aB}$ & $3.5 \mathrm{bA}$ & $0.7 \mathrm{bA}$ & $0.7 \mathrm{bA}$ \\
L 221 & $16.3 \mathrm{aB}$ & $28.1 \mathrm{bA}$ & $4.8 \mathrm{bB}$ & $5.7 \mathrm{fA}$ & $1.5 \mathrm{aB}$ & $5.0 \mathrm{aA}$ & $0.7 \mathrm{bA}$ & $0.8 \mathrm{bA}$ \\
L 159 & $18.0 \mathrm{aB}$ & $30.7 \mathrm{aA}$ & $2.7 \mathrm{~dB}$ & $7.7 \mathrm{dA}$ & $1.7 \mathrm{aB}$ & $2.6 \mathrm{bA}$ & $1.2 \mathrm{aA}$ & $1.2 \mathrm{aA}$ \\
L 234 & $18.5 \mathrm{aB}$ & $27.7 \mathrm{bA}$ & $5.2 \mathrm{bB}$ & $10.1 \mathrm{bA}$ & $2.1 \mathrm{aB}$ & $3.4 \mathrm{bA}$ & $0.5 \mathrm{bB}$ & $1.0 \mathrm{bA}$ \\
L 246 & $17.6 \mathrm{aB}$ & $28.4 \mathrm{bA}$ & $6.9 \mathrm{aB}$ & $8.9 \mathrm{cA}$ & $1.1 \mathrm{aB}$ & $3.2 \mathrm{bA}$ & $0.6 \mathrm{bB}$ & $0.8 \mathrm{bA}$ \\
L 77 & $16.2 \mathrm{aB}$ & $24.7 \mathrm{cA}$ & $5.2 \mathrm{bB}$ & $9.1 \mathrm{cA}$ & $1.3 \mathrm{aB}$ & $3.1 \mathrm{bA}$ & $0.6 \mathrm{bB}$ & $0.8 \mathrm{bA}$ \\
\hline Mean & 16.39 & 26.78 & 4.31 & 8.71 & 1.80 & 3.31 & 0.86 & 0.98 \\
\hline C.V.\% & \multicolumn{9}{c}{5.66} & 6.26 & & 9.11 & & 8.12 \\
\hline
\end{tabular}

*Means not followed by the same lowercase letter on the column differ by Scott-Knott's test (p-value $=0.05)$ and uppercase letter on the line differ by Student's $t$-test (p-value $=0.05$ )

With the exception of BRS Expedito, L 236 and L 175, all other lines exhibited high calcium concentration in leaves when grown at low calcium concentration. Therefore, it was possible to select common bean lines with higher ability to accumulate calcium in leaves (Carioca, $\mathrm{L}$ 15, L 200, L 74, L 221, L 159, L 234, L 246 and L77), even when grown in environment with restricted calcium.

The calcium concentration in grains varied from $0.5 \mathrm{~g} \mathrm{~kg}^{-1} \mathrm{DM}$ (L 234 at low calcium concentration) to $1.4 \mathrm{~g} \mathrm{~kg}^{-1} \mathrm{DM}$ (BRS Expedito and L 175 grown at low and at high calcium concentration, respectively) (Table 2). Similar calcium values in grains were observed segregating populations (JOST et al., 2009) and in inbred lines of common bean grown in Brazil (RIBEIRO et al., 2013). In the present work, the higher values of calcium concentration in the grains were obtained for BRS Expedito, Carioca, L 236, L 175, L 200 and L 159 at low calcium concentration and for BRS Expedito, L 175 and L 159 at high calcium concentration.

None of the tested lines exceeded BRS Expedito regarding calcium concentration in the grains. Among the cultivars nowadays in use in Brazil, BRS Expedito is a cultivar that has highest calcium concentration in grains (JOST et al., 2013) and so it was used as a control in this study. However, L 175 and L 159 lines showed calcium accumulation in grains similar to BRS Expedito, when grown under low and high calcium availability. Therefore, the selection of L 175 and L 159 lines will be prioritized by the breeding program due to the high calcium concentration in grains $\left(>1.1 \mathrm{~g} \mathrm{~kg}^{-1} \mathrm{DM}\right)$, regardless of the calcium availability in the rooting medium.

The L 15 and L 246 lines showed higher calcium use efficiency in grains (UEG) (Table 3), that is, exhibited higher grain yield at low calcium availability in the nutrient solution (Table 1). Now, the L 15 and L 77 lines showed highest values for calcium use efficiency in shoot (UES), differing significantly from the other lines grown at low calcium availability in the nutrient solution (Table 3). BRS Expedito, Carioca, L 236, L 175, L 200, L 74, L 221, L 159, L 234 and L 246 lines, in turn, are inefficient in calcium use in shoot because they obtained lower dry mass of shoot at low calcium concentration in the nutrient solution.

The L 15 line was calcium use efficiency in plant (UEP) (Table 3). This is a consequence of the high dry mass of shoot and high grain yield obtained at low calcium concentration in the nutrient solution (Table 1). Now, the L 15, L 234 and L 246 lines showed high calcium acquisition efficiency (CAE), differing significantly from the other lines. These lines presented high absorption capacity and calcium accumulation 
in shoot and grains, thus this index was efficient to identify common bean plants in the present research.

The L 15 and L 246 lines showed higher calcium use efficiency in grain production (UEGP) (Table 3). These lines were the most efficient in the conversion of calcium for grain production at low calcium availability (Table 1), and are therefore promising for grown under this condition.

The identification of common bean lines responsive to calcium application in the solution, similarly to the calcium use efficiency, was also not constant with the

Table 3 - Mean values* for calcium use efficiency in grain (UEG, $\mathrm{g}^{2} \mathrm{mg} \mathrm{Ca}^{-1}$ ), calcium use efficiency in shoot (UES, $\mathrm{g}^{2} \mathrm{mg}^{-1}$ ), calcium use efficiency in plant (UEP, $\mathrm{g}^{2} \mathrm{mg}^{-1}$ ), calcium acquisition efficiency (CAE, $\mathrm{g}^{2} \mathrm{mg}^{-1}$ ), calcium use efficiency in grain production (UEGP, $\mathrm{g}^{2} \mathrm{mg}^{-1}$ ), calcium response index to grain production (RIGP), calcium response index to shoot dry mass production (RISDM) and calcium response index to plant dry mass production (RIPDM) obtained for 12 common bean lines grown under two calcium concentrations in the nutrient solution

\begin{tabular}{|c|c|c|c|c|c|c|c|}
\hline \multirow{2}{*}{ Line } & \multicolumn{2}{|c|}{ UEG } & \multicolumn{3}{|c|}{ UES } & \multicolumn{2}{|c|}{ UEP } \\
\hline & Low $\mathrm{Ca}$ & High Ca & \multicolumn{2}{|c|}{ Low $\mathrm{Ca}$} & High Ca & Low $\mathrm{Ca}$ & High $\mathrm{Ca}$ \\
\hline BRS Expedito & $0.035 \mathrm{cB}$ & $0.144 \mathrm{cA}$ & \multicolumn{2}{|c|}{$0.011 \mathrm{cB}$} & $0.003 \mathrm{cA}$ & $0.022 \mathrm{eA}$ & $0.016 \mathrm{~dB}$ \\
\hline Carioca & $0.078 \mathrm{cB}$ & $0.277 \mathrm{bA}$ & \multicolumn{2}{|c|}{$0.012 \mathrm{cB}$} & $0.016 \mathrm{bA}$ & $0.026 \mathrm{eB}$ & $0.042 \mathrm{bA}$ \\
\hline L 236 & $0.030 \mathrm{cB}$ & $0.235 \mathrm{bA}$ & \multicolumn{2}{|c|}{$0.012 \mathrm{cA}$} & $0.015 \mathrm{bA}$ & $0.022 \mathrm{eB}$ & $0.041 \mathrm{bA}$ \\
\hline L 175 & $0.021 \mathrm{cB}$ & $0.079 \mathrm{dA}$ & \multicolumn{2}{|c|}{$0.011 \mathrm{cA}$} & $0.005 \mathrm{cB}$ & $0.018 \mathrm{eA}$ & $0.015 \mathrm{dA}$ \\
\hline L 15 & $0.637 \mathrm{aA}$ & $0.195 \mathrm{cB}$ & \multicolumn{2}{|c|}{$0.043 \mathrm{aA}$} & $0.033 \mathrm{aB}$ & $0.105 \mathrm{aA}$ & $0.062 \mathrm{aB}$ \\
\hline L 200 & $0.018 \mathrm{cB}$ & $0.161 \mathrm{cA}$ & \multicolumn{2}{|c|}{$0.019 \mathrm{cA}$} & $0.014 \mathrm{bA}$ & $0.026 \mathrm{eA}$ & $0.032 \mathrm{cA}$ \\
\hline L 74 & $0.068 \mathrm{cB}$ & $0.288 \mathrm{bA}$ & \multicolumn{2}{|c|}{$0.030 \mathrm{bA}$} & $0.003 \mathrm{cB}$ & $0.046 \mathrm{dA}$ & $0.013 \mathrm{~dB}$ \\
\hline L 221 & $0.083 \mathrm{cB}$ & $0.257 \mathrm{bA}$ & & $\mathrm{cB}$ & $0.022 \mathrm{aA}$ & $0.019 \mathrm{eB}$ & $0.047 \mathrm{bA}$ \\
\hline L 159 & $0.046 \mathrm{cB}$ & $0.167 \mathrm{cA}$ & 0.0 & $\mathrm{cB}$ & $0.016 \mathrm{bA}$ & $0.017 \mathrm{eB}$ & $0.038 \mathrm{cA}$ \\
\hline L 234 & $0.256 \mathrm{bA}$ & $0.254 \mathrm{bA}$ & & $\mathrm{bA}$ & $0.014 \mathrm{bB}$ & $0.058 \mathrm{cA}$ & $0.037 \mathrm{cB}$ \\
\hline L 246 & $0.645 \mathrm{aA}$ & $0.401 \mathrm{aB}$ & & $\mathrm{bA}$ & $0.009 \mathrm{cB}$ & $0.094 \mathrm{bA}$ & $0.033 \mathrm{cB}$ \\
\hline L 77 & $0.291 \mathrm{bB}$ & $0.425 \mathrm{aA}$ & & $\mathrm{aA}$ & $0.027 \mathrm{aB}$ & $0.092 \mathrm{bA}$ & $0.068 \mathrm{aB}$ \\
\hline Mean & 0.184 & 0.240 & 0.0 & & 0.015 & 0.045 & 0.037 \\
\hline C.V.\% & & 21.29 & & & 11.79 & & 11.02 \\
\hline$I \cdot$ & & & & & & & \\
\hline LIIIU & Low $\mathrm{Ca}$ & High Ca & Low $\mathrm{Ca}$ & High Ca & NI & Nin & KII DIV \\
\hline BRS Expedito & $10.3 \mathrm{cB}$ & $36.7 \mathrm{bA}$ & $0.002 \mathrm{dA}$ & $0.005 \mathrm{cA}$ & $0.064 \mathrm{a}$ & $-0.032 \mathrm{e}$ & $0.032 \mathrm{~d}$ \\
\hline Carioca & $12.9 \mathrm{bB}$ & $37.1 \mathrm{bA}$ & $0.003 \mathrm{~dB}$ & $0.007 \mathrm{bA}$ & $0.071 \mathrm{a}$ & $0.080 \mathrm{~b}$ & $0.151 \mathrm{~b}$ \\
\hline L 236 & $8.9 \mathrm{cB}$ & $27.1 \mathrm{dA}$ & $0.002 \mathrm{~dB}$ & $0.006 \mathrm{bA}$ & $0.084 \mathrm{a}$ & $0.070 \mathrm{~b}$ & $0.155 \mathrm{~b}$ \\
\hline L 175 & $10.3 \mathrm{cB}$ & $40.1 \mathrm{aA}$ & $0.001 \mathrm{~dB}$ & $0.003 \mathrm{dA}$ & $0.051 \mathrm{a}$ & $0.002 \mathrm{~d}$ & $0.054 \mathrm{~d}$ \\
\hline L 15 & $15.2 \mathrm{aB}$ & $29.5 \mathrm{dA}$ & $0.014 \mathrm{aA}$ & $0.005 \mathrm{cB}$ & $-0.052 c$ & $0.008 \mathrm{~d}$ & $-0.044 \mathrm{e}$ \\
\hline L 200 & $12.9 \mathrm{bB}$ & $36.8 \mathrm{bA}$ & $0.001 \mathrm{~dB}$ & $0.004 \mathrm{dA}$ & $0.074 \mathrm{a}$ & $0.029 \mathrm{c}$ & $0.102 \mathrm{c}$ \\
\hline L 74 & $12.9 \mathrm{bB}$ & $42.5 \mathrm{aA}$ & $0.002 \mathrm{~dB}$ & $0.004 \mathrm{cA}$ & $0.064 \mathrm{a}$ & $-0.148 \mathrm{~g}$ & $-0.084 \mathrm{f}$ \\
\hline L 221 & $12.6 \mathrm{bB}$ & $36.3 \mathrm{bA}$ & $0.003 \mathrm{~dB}$ & $0.005 \mathrm{cA}$ & $0.062 \mathrm{a}$ & $0.141 \mathrm{a}$ & $0.202 \mathrm{a}$ \\
\hline L 159 & $13.0 \mathrm{bB}$ & $41.2 \mathrm{aA}$ & $0.002 \mathrm{~dB}$ & $0.005 \mathrm{cA}$ & $0.063 \mathrm{a}$ & $0.126 \mathrm{a}$ & $0.189 \mathrm{a}$ \\
\hline L 234 & $15.9 \mathrm{aB}$ & $41.0 \mathrm{aA}$ & $0.004 \mathrm{cA}$ & $0.006 \mathrm{cA}$ & $0.045 \mathrm{a}$ & $-0.042 \mathrm{e}$ & $0.003 \mathrm{~d}$ \\
\hline L 246 & $15.9 \mathrm{aB}$ & $39.4 \mathrm{aA}$ & $0.015 \mathrm{aA}$ & $0008 \mathrm{bB}$ & $-0.016 b$ & $-0.101 \mathrm{f}$ & $-0.118 \mathrm{f}$ \\
\hline L 77 & $12.5 \mathrm{bB}$ & $33.1 \mathrm{cA}$ & $0.007 \mathrm{bB}$ & $0009 \mathrm{aA}$ & $0.057 \mathrm{a}$ & $-0.017 \mathrm{e}$ & $0.039 \mathrm{~d}$ \\
\hline Mean & 12.8 & 36.7 & 0.005 & 0010 & 0.047 & 0.010 & 0.057 \\
\hline C.V.\% & & 7.15 & & 21.31 & 21.09 & 17.50 & 24.65 \\
\hline
\end{tabular}

*Means not followed by the same lowercase letter on the column differ by Scott-Knott's test (p-value $=0.05)$ and uppercase letter on the line differ by Student's $t$-test (p-value $=0.05$ ) 
index used (Table 3). The calcium response index to grain production (RIGP) identified BRS Expedito, Carioca, L 236, L 175, L 200, L 74, L 221, L 159, L 234 and L77 lines as responsive to the application of calcium in the nutrient solution. However, the calcium response index to shoot dry mass production (RISDM) and the calcium response index to plant dry mass production (RIPDM) were consistent in identifying common bean lines responsive to the application of calcium in the nutrient solution: L 221 and L 159.

The relationship between calcium use efficiency in shoot (UES) and calcium response index to shoot dry mass production (RISDM) is shown in Figure 1A. Four groups of lines could be identified: (1) efficient and responsive: L 15; (2) inefficient and responsive: L 221,
L 159, Carioca, L 236 and L 200; (3) inefficient and unresponsive: L 175 and BRS Expedito; and (4) efficient and unresponsive: L 234, L 77, L 246 and L 74.

The lines in groups 1 and 4 were classified as efficient in calcium use in shoot, because at low calcium concentration in the solution, they reached dry mass of shoot above the overall mean (Table 1). The $\mathrm{L}$ 15, L 234, L 77, L 246 and L 74 lines, even when grown under low calcium availability, showed no limitation in the vegetative growth. The lines of groups 1 and 2 were classified as responsive to the application of calcium in the nutrient solution, as they presented an increase in dry mass of shoot when grown at high calcium concentration. Therefore, the grown of the L 15, L 221,

Figure 1 - Classification of 12 common bean lines regarding the calcium use efficiency in shoot (UES) relative to calcium response index to shoot dry mass production (RISDM) (A), calcium use efficiency in plant (UEP) relative to calcium response index to plant dry mass production (RIPDM) (B), calcium acquisition efficiency (CAE) relative to calcium response index to grain production (RIGP) (C) and calcium use efficiency in grain production (UEGP) relative to calcium response index to grain production (RIGP) (D) obtained at low calcium concentration in the nutrient solution; ER: efficient and responsive; INR: inefficient and responsive; INUR: inefficient and unresponsive; and EUR: efficient and unresponsive; 1- BRS Expedito; 2 Carioca; 3- L 236; 4- L 175; 5- L 15; 6- L 200; 7- L 74; 8- L 221; 9- L 159; 10- L 234; 11- L 246; and 12- L 77

A

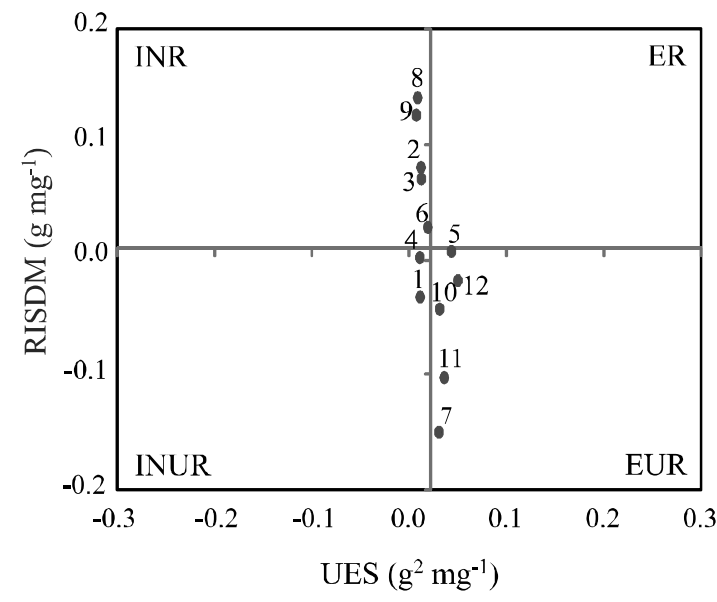

C

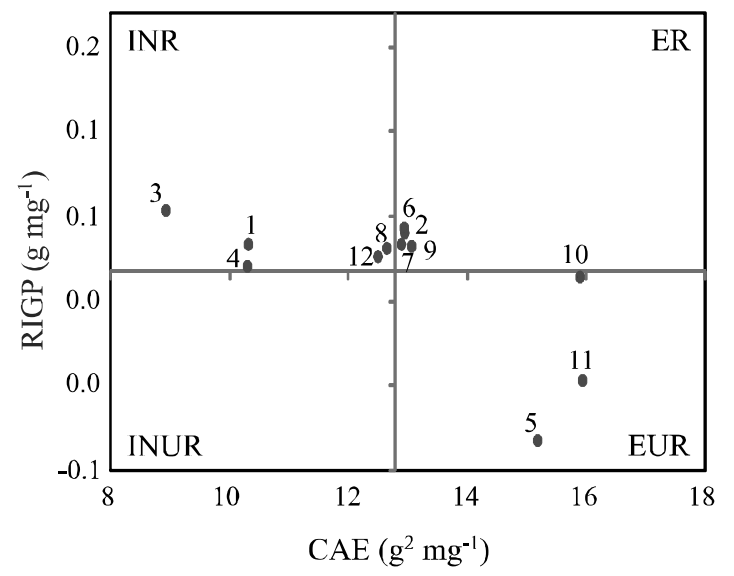

B

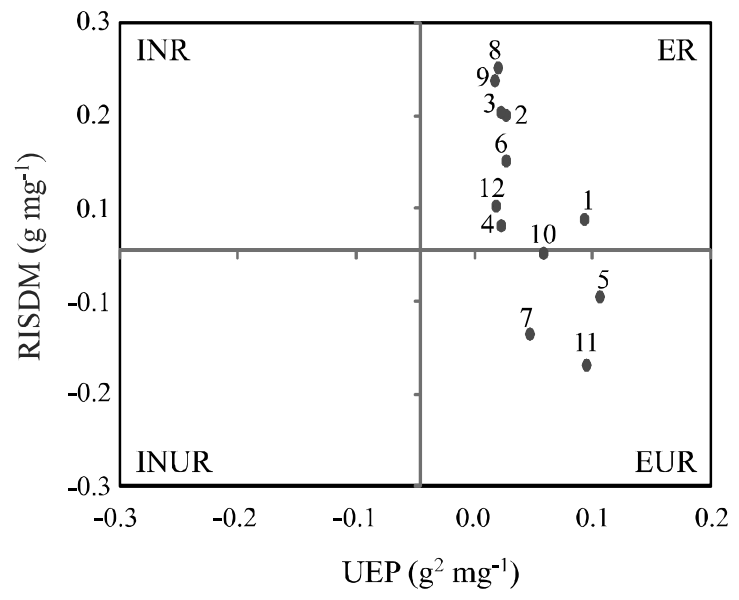

$\mathrm{D}$

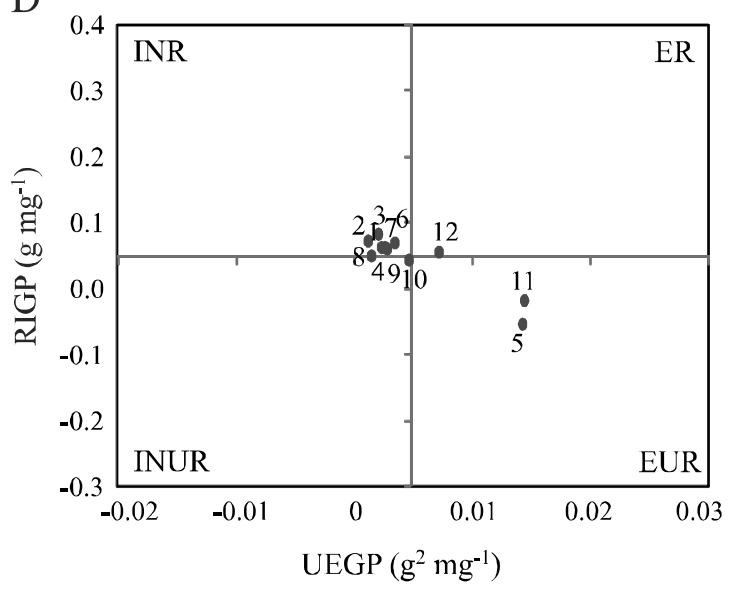


L 159, Carioca, L 236 and L 200 lines will be enhanced in an environment with high calcium availability.

With respect to calcium use efficiency in plant (UEP) and the calcium response index to plant dry matter production (RIPDM) (Figure 1B), only two groups of the lines could be identified: efficient and responsive (L 221, L 159, L 236, Carioca, L 200, L 77, L 175, L 234 and BRS Expedito) and efficient and unresponsive (L 74, L 15 and L 246). According to this index, all lines were efficient in calcium use in plant. However, using this same index, Santos and Fageria (2007) were able to identify common bean cultivars efficient and inefficient in nitrogen use in lowland soils. In the present experiment, the lines differed to the supply of calcium in the nutrient solution. The L 221, L 159, L 236, Carioca, L 200, L 77, L 175, L 234 and BRS Expedito lines were responsive to calcium nutrition. Therefore, it can be hypothesized that shoot dry mass production and grain yield of these common bean lines should be increased by calcium fertilization.

According to the relationship between the calcium acquisition efficiency (CAE) and the calcium response index to grain production (RIGP) (Figure 1C), three groups were formed: efficient and responsive (L 200, Carioca, L 159 and L 74), inefficient and responsive (L 236, BRS Expedito, L 175, L 221 and L 77) and efficient and unresponsive (L 15, $\mathrm{L} 246$ and $\mathrm{L}$ 234). The lines efficient in calcium acquisition (L 200, Carioca, L 159, L 74, L 15, L 246 and L 234) must have a higher capacity for calcium assimilation, which was converted into higher grain yield.

The relationship between calcium use efficiency in grain production (UEGP) and the calcium response index to grain production (RIGP), enabled the formation of three groups of lines: efficient and responsive: L 77, inefficient and unresponsive: Carioca, L 236, L 200, L 74, L 221, BRS Expedito, L 175, L 159 and L 234; and efficient and unresponsive: L 246 and L 15 (Figure 1D). The L 77, L 246 and L 15 lines were efficient in calcium use, that is, under conditions of calcium restriction in the rooting medium, they presented higher grain yield than the general mean (Table 1). However, only L77 line was responsive the application of calcium in the nutrient solution. The 77 line showed highest grain yield under grown in low and high calcium availability e therefore the selection of this line is recommended by breeding program. In an experiment conducted in the field, Souza et al. (2012) identified two common bean cultivars as efficient and responsive to nitrogen, using the same methodology. The L 246 and L 15 lines showed grain yield above the general mean at low calcium concentration, but grain yield was reduced at high calcium concentration (Table 1). The L 246 and L 15 lines were adapted only for grown in low calcium availability in the rooting medium. That's because these lines were efficient, but not responsive to calcium in the rooting medium.
The L15 line was identified as efficient in calcium use by all indexes used in this study: UEG, UES, EUP, CAE and UEGP (Table 3, Figure 1). This is due to the fact that the L 15 line showed low calcium requirement for shoot dry mass production and for grain yield (Table 1). Therefore, even under conditions of low calcium availability in the rooting medium, L 15 line was more efficient in absorption and accumulation calcium in shoot and grains and this resulted in vigorous shoot growth and increased grain yield. This is the first report of selection of a common bean line efficient in calcium use. The L 15 line will be assessed as to its value for cultivation and use under field conditions to validate its indication for low technology grown. The L15 line will also be used in controlled hybridization programs aimed at developing new common bean lines efficient in calcium use.

The L 221 and L 159 lines were classified as responsive to the application of calcium in the rooting medium by RIGP, RISDM and RIPDM indexes (Table 3, Figure 1), because at high calcium availability they reached higher shoot dry mass production and grain yield (Table 1). Therefore, validation of these results will be sought under field conditions. If there would be repeatability in such results, the L 221 and L 159 lines could be registered as new common bean cultivars to be grown using calcium fertilization.

\section{CONCLUSION}

The L 15 line presents a low calcium requirement for the production of dry mass of shoot, pods, grains, grains per pod and grain yield. Calcium accumulation in tissues is, on average, higher in leaves, followed by stems, pods and grains. The L15 line is efficient in calcium use. The L 221 and L 159 lines are responsive to the application of calcium in the rooting medium.

\section{REFERENCES}

BAILIAN, L.; MCKEAND, S. E.; ALLEN, H. L. Genetic variation in nitrogen use efficiency of lobeolly pine seedlings. Forest Science, v. 37, n. 2, p. 613-626, 1991.

BATTEN, G. D.; KHAN, M. A.; CULLIS, B. R. Yield responses by modern wheat genotypes to phosphate fertilizer for breeding. Euphytica, v. 33, n. 1, p. 81-89, 1984.

CRUZ, C. D. Genes - a software package for analysis in experimental statistics and quantitative genetics. Acta Scientiarum, v. 35, n. 3, p. 271-276, 2013.

FAGERIA, N. K. Otimização da eficiência nutricional na produção das culturas. Revista Brasileira de Engenharia Agrícola e Ambiental, v. 2, n. 1, p. 6-16, 1998.

FAGERIA, N. K. et al. Dry bean genotypes evaluation for growth, yield components and phosphorus use efficiency. Journal of Plant Nutrition, v. 33, n. 14, p. 2167-2181, 2010. 
FAGERIA, N. K.; BARBOSA FILHO, M. P.; COSTA, J. G. C. Potassium-use efficiency in common bean genotypes. Journal of Plant Nutrition, v. 24, n. 12, p. 1937-1945, 2001.

FAVARO, S. P. et al. Rates of calcium, yield and quality of snap bean. Scientia Agricola, v. 64, n. 6, p. 616-620, 2007.

FROSSARD, E. et al. Potential for increasing the content and bioavailability of $\mathrm{Fe}, \mathrm{Zn}$ and $\mathrm{Ca}$ in plants for human nutrition. Journal of the Science of Food and Agriculture, v. 80 , n. 7 , p. $861-879,2000$

FURLANI, A. M. C. et al. Variability of soybean germplasm in relation to phosphorus uptake and use efficiency. Scientia Agricola, v. 59, n. 3, p. 529-536, 2002.

FURTINI, I. V. Implicações da seleção no feijoeiro efetuada em ambientes contrastantes em níveis de nitrogênio. 2008. 67 f. Dissertação (Mestrado em Genética e Melhoramento), Universidade Federal de Lavras, Lavras, 2008.

GE, L. L.; TIAN, H. Q.; RUSSEL, S. D. Calcium function and distribution during fertilization in angiosperms. American Journal of Botany, v. 94, n. 6, p. 1046-1060, 2007.

GILliHAM, M. et al. Calcium delivery and storage in plant leaves: exploring the link with water flow. Journal of Experimental Botany, v. 62, n. 7, p. 2233-2250, 2011.

GONDIN, A. R. O. et al. Eficiência nutricional do milho cv. BRS 1030 submetido à omissão de macronutrientes em solução nutritiva. Revista Ceres, v. 57, n. 4, p. 539-544, 2010.

GOOD, A. G.; SHRAWAT, A. K.; MUENCH, D. G. Can less yield more? Is reducing nutrient input into the environment compatible with maintaining crop production? Trends in Plant Science, v. 9, n. 12, p. 597-605, 2004.

HENRY, A. et al. Will nutrient-efficient genotypes mine the soil? Effects of genetic differences in root architecture in common bean (Phaseolus vulgaris L.) on soil phosphorus depletion in a low-input agro-ecosystem in Central America. Field Crops Research, v. 115, n. 1, p. 67-78, 2010.

JOST, E. et al. Efeitos gênicos do teor de cálcio em grãos de feijão. Ciência Rural, v. 39, n. 1, p. 31-37, 2009.

JOST, E. et al. Comparison among direct, indirect and index selections on agronomic traits and nutritional quality traits in common bean. Journal of the Science of Food and Agriculture, v. 93, n. 5, p. 1097-1104, 2013.

MENDONÇA, R. J. et al. Efeito do alumínio na absorção e na utilização de macronutrientes em duas cultivares de arroz. Pesquisa Agropecuária Brasileira, v. 38, n. 7, p. 843-848, 2003.

MIYAZAWA, M.; PAVAN, M. A.; BLOCH, M. F. Análises químicas de tecido vegetal. In: SILVA, F. C. Manual de análises químicas de solos, plantas e fertilizantes. Brasília: Embrapa Solos, 1999. p. 171-223.

POMPER, K. W.; GRUSAK, M. A. Calcium uptake and whole-plant water use influence pod calcium concentration in snap bean plants. Journal of the American Society for Horticultural Science, v. 129, n. 6, p. 890-895, 2004.

RIBEIRO, N. D. et al. Combined selection for grain yield, cooking quality and minerals in the common bean. Revista Ciência Agronômica, v. 44, n. 4, p. 869-877, 2013.

ROSE, T. J.; WISSUWA, M. Rethinking internal phosphorus utilization efficiency: a new approach is needed to improve PUE in grain crops. Advances in Agronomy, v. 116, p. 185217, 2012.

SANTOS, A. B.; FAGERIA, N. K. Manejo do nitrogênio para eficiência de uso por cultivares de feijoeiro em várzea tropical. Pesquisa Agropecuária Brasileira, v. 42, n. 9, p. 1237-1248, 2007.

SIDDIQI, M. Y.; GLASS, A. D. M. Utilization index: a modified approach to the estimation and comparison of nutrient utilization efficiency in plants. Journal of Plant Nutrition, v. 4, n. 3, p. 289-302, 1981.

SILVA, S. A.; MORAES, W. B.; SOUZA, G. S. Doses de cálcio no crescimento do feijoeiro cultivado em solução nutritiva, na presença de alumínio. Idesia, v. 29, n. 3, p. 53-58, 2011.

SOUZA, A. S. et al. Eficiência e resposta à aplicação de nitrogênio de genótipos de feijão comum cultivados em várzea tropical do Estado do Tocantins. Journal of Biotechnology and Biodiversity, v. 3, n. 3, p. 31-37, 2012.

SPEHAR, C. R.; GAWEY, N. W. Screening soya beans [Glycine $\max$ (L.) Merill] for calcium efficiency by root growth in low-Ca nutrient solution. Euphytica, v. 94, n. 1, p.113-117, 1997. 